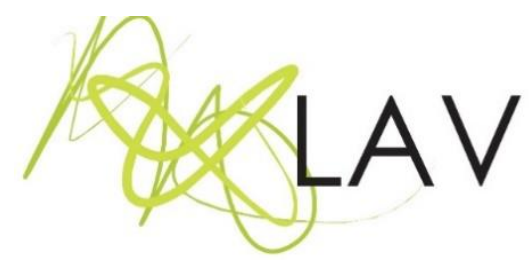

\title{
De uma história a outra, a professora que sou
}

From a story to another, the teacher Iam

Rosvita Kolb Bernardesi

Escola de Belas Artes/UFMG

\begin{abstract}
Resumo
Esse artigo traz pequenas histórias, fragmentos de práticas docentes e artísticas. São narrativas vividas, escolhidas e experienciadas em tempos e espaços diferentes, tecidas pelo fio da memória em um intenso movimento de ressignificação. São construções biográficas que se cruzam entre lugares e objetos, em momentos vividos entre a escola, a infância, a docência e a arte. Inspirado em Walter Benjamin, mergulha nas histórias narradas, construindo um conjunto de mônadas ou miniaturas de significados, que trazem uma perspectiva autoinvestigativa, potencializadora, onde a ação do rememorar tem um papel fundamental. É na experiência do outro que um se vê e se revê. É na experiência da sala de aula, na escola, junto com as crianças, que esse um alimenta-se como professora-artista. Em um movimento contínuo e circular, carrega consigo esse alimento para a universidade, para os alunos da Licenciatura, para o processo de criação e invenção.
\end{abstract}

Palavras-chave: memória, biografia, docência, arte.

\begin{abstract}
This article brings short stories, fragments of teaching and artistic practices. They are narratives lived, chosen and experienced in different times and spaces, interweaved by the wires of memory, in an intense resignification movement. They are biographical constructions that intersect themselves between places and objects, in moments lived among school, childhood, teaching and art. Inspired by Walter Benjamin, it immerses in the narrated stories, building a set of monads or miniatures of meanings that bring a self-exploring, empowering perspective, where remembering plays a key role. It is in the other's experience that one sees and revisits him/herself. It is in the experience of the classroom, at school, along with the students, that he/she feeds him/herself as a teacher-artist. In a continuous and circular movement, he/she carries this nourishment to the university, to the teachers to be, to the process of creation and invention.
\end{abstract}

Keywords: memory, biography, teaching, art.

Enviado em: 01/06/18 - Aprovado em: 17/07/18

\section{Costurar e emendar}

[...] e à medida que o papel abria caminho à agulha com um leve estalo, eu cedia à tentação de apaixonar pelo reticulado do avesso que ia ficando mais confuso a cada ponto dado, com o qual, no direito, me aproximava da meta (BENJAMIN, 1994, p. 129).

Revista Digital do LAV - Santa Maria - vol. 11, n. 2, p. 230 - 244 - mai./ago. 2018 ISSN 1983 - 7348 http://dx.doi.org/10.5902/1983734832833905 
Escolher, esticar, cortar, sentir e desenhar a primeira linha no pano sempre é algo muito vago para mim. Nunca sei exatamente onde começa e onde acaba. Por outro lado, costurar, emendar, remendar provocam em mim uma sensação de pertencimento.

Sinto que as ideias me pertencem, mas a agulha não. Ela segue o seu caminho, furando, marcando, abrindo o tecido. Olho e vejo o seu trajeto, caminhando sobre a superfície na qual, nem sempre, me reconheço. Ela não para. Segue o seu percurso, puxando um fio, outro fio, mais um fio. Num movimento contínuo, quase infinito.

Vejo e observo o meu percurso, o de combinar as cores, de esticar os fios, de dobrar e desdobrar o pano, como uma conversa, onde coloco o fio na agulha e imagino o desenho. Este movimento de juntar, escolher, cortar, emendar traz uma gestualidade para o meu trabalho que me agrada muito. Há tempos ando por este caminho da costura, "da fazeção de coisas", com os panos, as agulhas, linhas e tecidos.

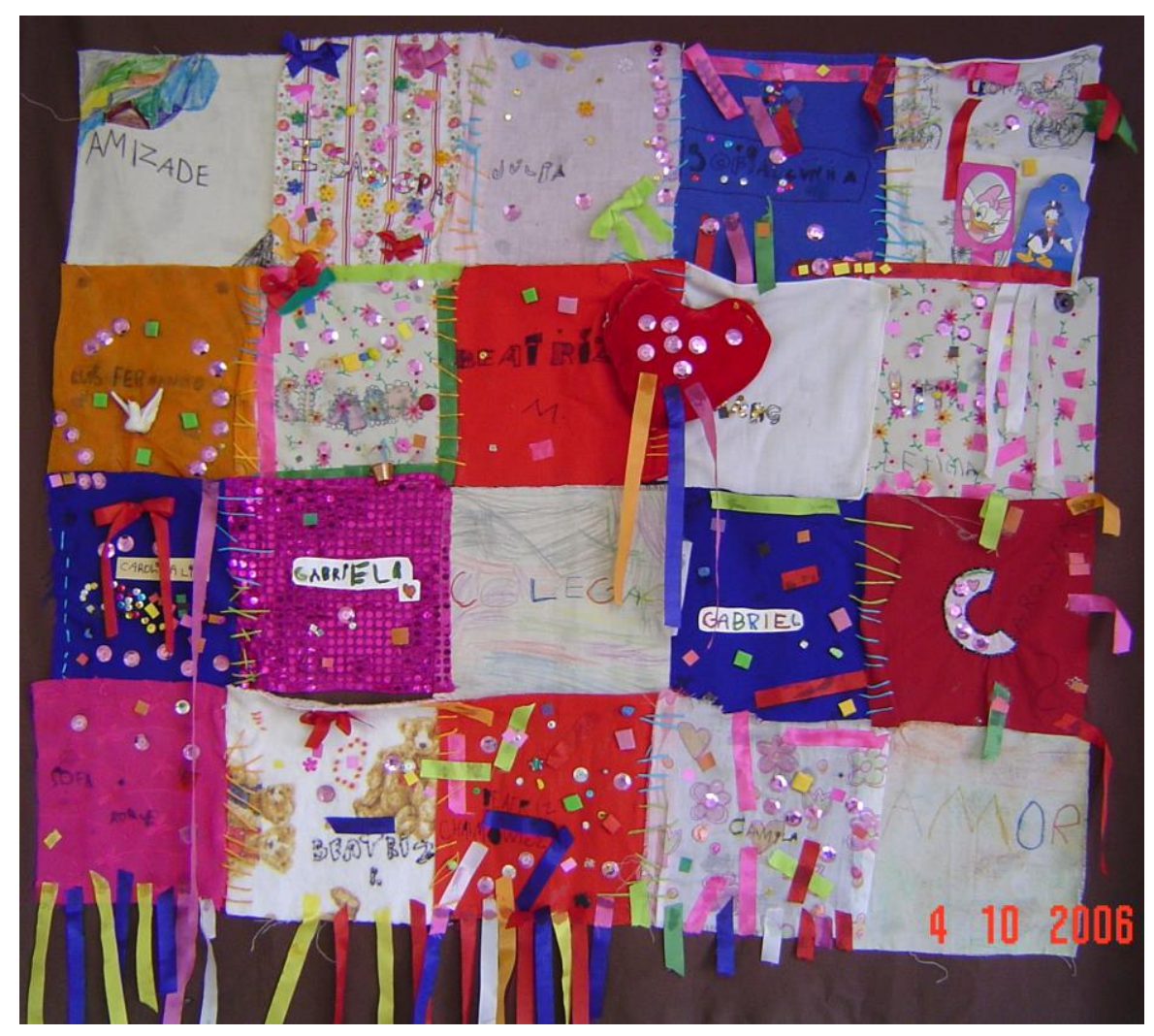

Figura 01. Colcha bordada

Nos diferentes lugares em que tenho trabalhado na cidade de Belo Horizonte, desde 1997, vivo experiências com a arte, as quais se construíram entre acertos e desacertos, certezas, dúvidas e angústias. Neste artigo escrevo sobre essas experiências, narrando- 
as por meio de mônadas, assim como Walter Benjamim (1994) o fez ao narrar suas experiências de infância no texto "Infância em Berlim por volta de 1990". Como afirma Maria Carolina Bovério Galzerani (2005, p. 62), "[...] mônadas ou miniaturas de significados" são "centelhas de sentido, que podem ter a força de um relâmpago".

Selecionei algumas histórias vividas por mim em tempos e épocas diferentes. Apesar de pequenas, são histórias carregadas de lembranças e de afeto, onde a ação do rememorar tem um papel fundamental. Desejo que as histórias aqui narradas possam chegar a cada leitor como "centelhas de sentido com a força de um relâmpago" (GALZERANI, 2005, p. $62)$.

\section{A cesta de costura}

[...] Além da parte superior da caixa, onde ficavam os carretéis uns ao lado dos outros, onde brilhavam as cartelas pretas das agulhas e onde as tesouras ficavam confinadas a suas capas de couro, havia o fundo escuro, a desordem, onde reinava 0 entrançado desfeito e onde sobras de elástico, ganchos, colchetes, retalhos de seda se amontoavam. Nesse refugo também havia botões; muitos de tal feitio como jamais se viu em roupa alguma [...] (BENJAMIN, 1987, p. 129).

Ao longo dos anos e em diferentes momentos, trabalhando como professora de arte com crianças no ensino fundamental e na universidade, pude incluir algumas experiências com o bordado e a costura nas minhas aulas. A seguir o diálogo com uma aluna em um destes momentos:

- Posso mostrar a caixa de costura que ganhei da minha avó?

- Você ganhou da sua avó?

- Sim. Ela sabe costurar e montou esta caixa para mim. Eu dormi ontem na casa dela, e de noite fizemos isso.

- Mostra a caixa para nós, Sofia! Ela é costureira?

- Isto eu não sei... mas acho que sim. Ela sabe costurar e já fez um vestido e uma blusa para mim.

Neste instante outras crianças já estavam interessadas na caixa. As perguntas foram muitas:

- Então eu acho que ela deve ser uma boa costureira.

- Sofia! Mas quanta coisa... dentro desta caixa... até dedal e fita métrica!?

Revista Digital do LAV - Santa Maria - vol. 11, n. 2, p. 230 - 244 - mai./ago. 2018 ISSN 1983 - 7348 http://dx.doi.org/10.5902/1983734832833905 
- E esses botões coloridos? O que você vai fazer com eles?

- Eu pensei... em usar nesse tecido aqui...

Essa conversa aconteceu entre crianças de 9 anos de idade, durante uma aula de arte. Já fazia algum tempo que eu estava trabalhando com esse grupo a costura e o bordado.

Todos nós ficamos encantados com a caixa de costura da aluna Sofia e com a iniciativa da sua avó.

Lembrei-me que, em algum momento da minha vida, também tive uma caixa como aquela. Busquei na minha memória alguma imagem semelhante. Assim, depois da aula, já no caminho de casa, lembrei-me que, aos 14 anos de idade, ganhei do meu padrinho uma cesta de costura.

Ansiosa por achar esse presente, cheguei em casa e abri portas, armários e muitas gavetas. Procurei em caixas, estantes e malas. E qual não foi a minha surpresa? Além de achar a cesta, encontrei dentro dela vários bordados e restos de tecidos, misturados no meio de fios, linhas e agulhas. Ao olhar para o objeto-cesta, já não me reconheci. "Aquele objeto de costura foi meu algum dia? Onde estão os meus bordados"? pensei.

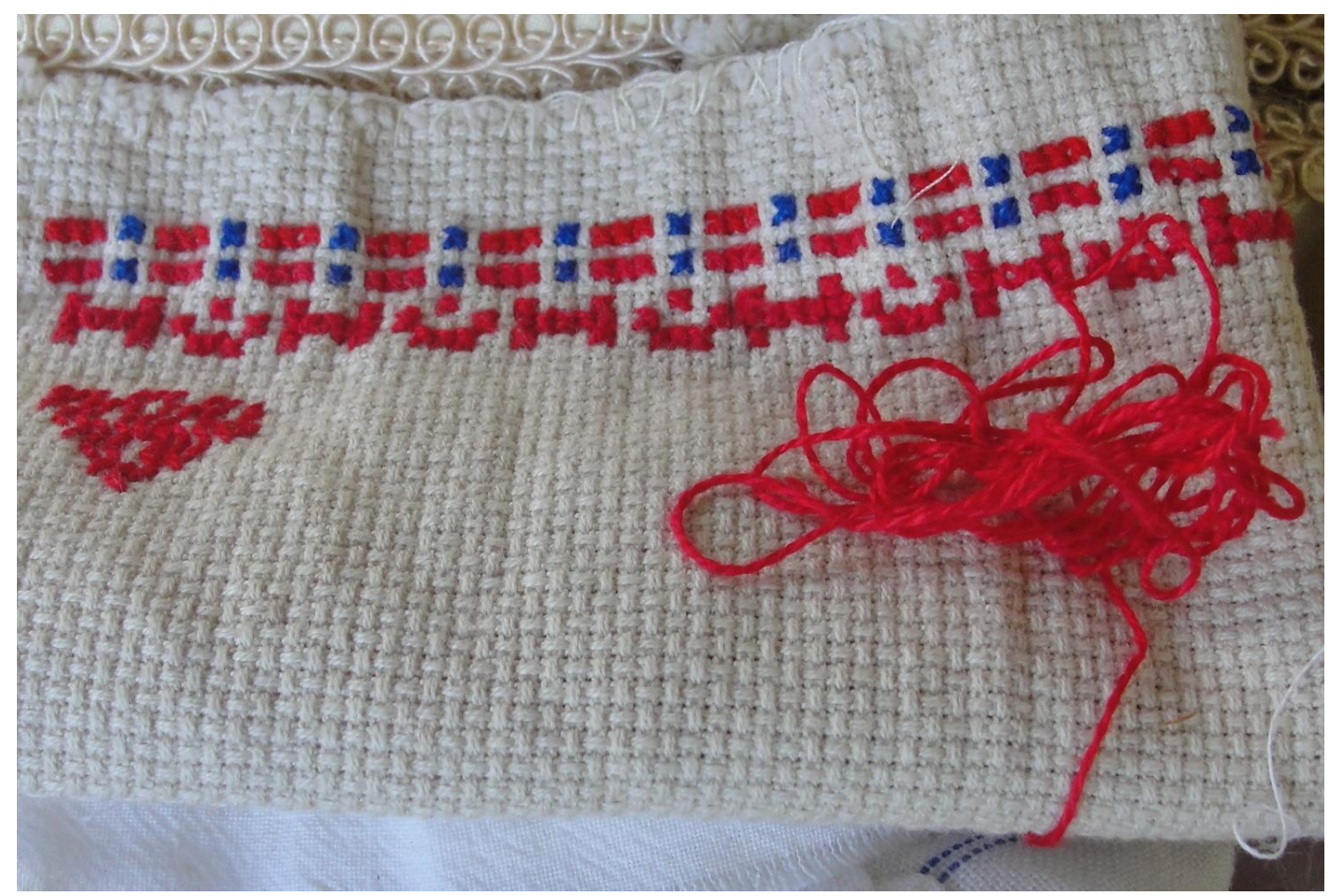

Figura 02. Memória de infância

Revista Digital do LAV - Santa Maria - vol. 11, n. 2, p. 230 - 244 - mai./ago. 2018 ISSN 1983 - 7348 http://dx.doi.org/10.5902/1983734832833905 


\section{A mesa de costura}

Os objetos em nossas vidas, distintos do modo como deles fazemos uso em um dado momento, representam algo muito mais profundamente relacionado à subjetividade (BAUDRILLARD, 2002, p. 94).

Antigamente, as casas tinham espaços para um quarto de costura. Eu gostava de ficar nesse quarto. No dia em que minha avó morreu, ganhei de presente a sua mesa de costura, junto com a caixa de costura de tecido feita por meu pai, aos 12 anos de idade, como um presente para a minha avó, no Dia das Mães de 1943. Talvez tenha sido isso o que aconteceu: Em algum momento da minha vida, a mesa de costura começou a representar a falta, a ausência da minha avó.

Hoje a mesa e a caixa de costura ainda me pertencem, fazem parte do cenário afetivo da minha casa. A minha avó e o meu pai já não vivem entre nós.

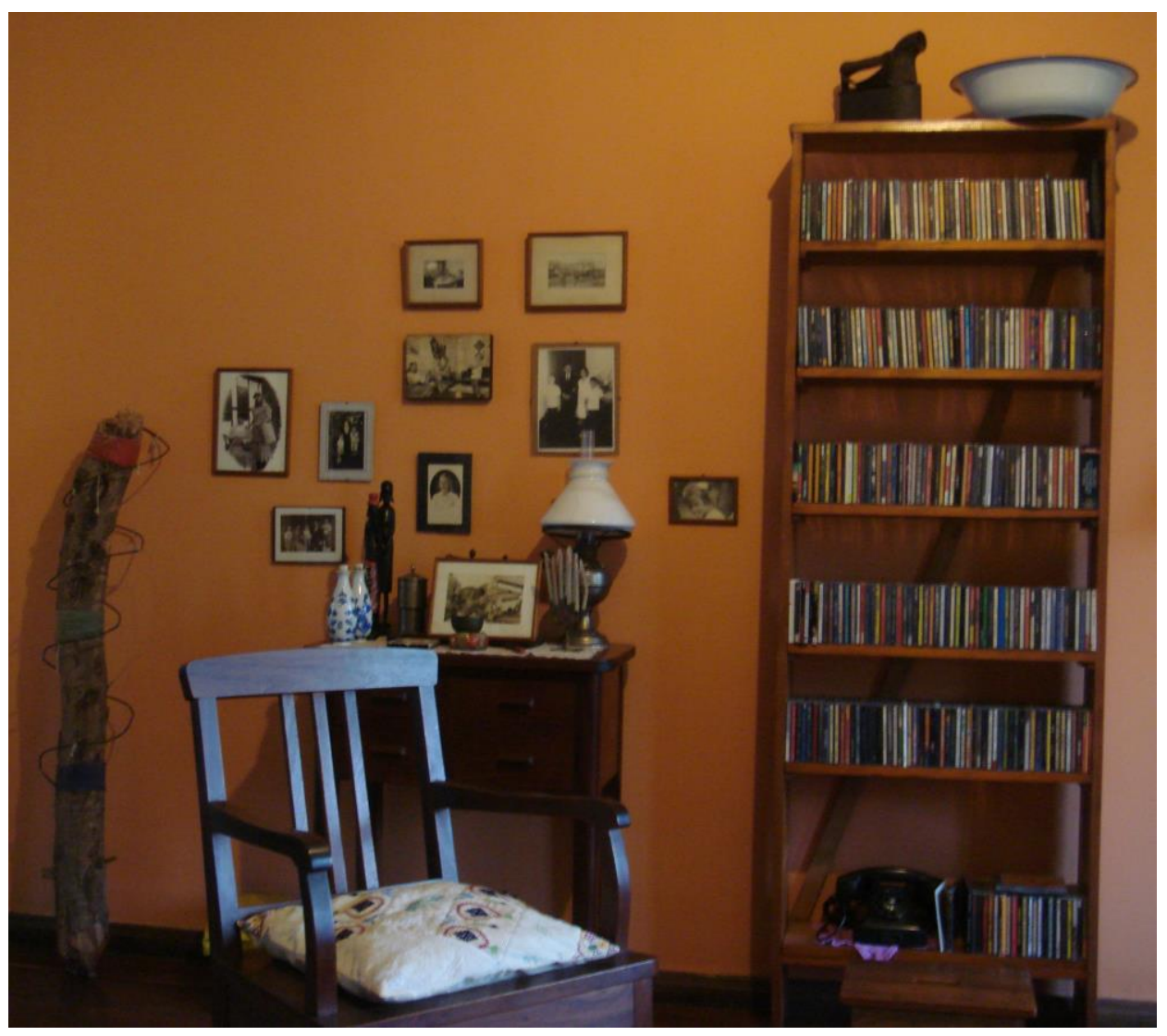

Figura 03. Mesa de costura 


\section{A dor e a acolhida}

Anos atrás recebi o convite para participar de uma exposição fotográfica intitulada: "O sentimento da dor, mulheres-artistas-educadoras", na Croácia.

Não consigo descrever o que me aconteceu e nem sei porquê fiquei tão sensibilizada por esse tema, mas sei que fiquei, por vários dias, num estado de profunda angústia. Sentiame sufocada por mim mesma.

Caminhei pela casa, de um lugar para outro, tentando entender o que estava acontecendo naquele momento. Busquei a mala.

Carrego comigo há anos uma mala. Ganhei essa mala dos meus avós. Ela veio com eles quando imigraram, em 1930, da Alemanha para o Brasil. Essa mala acompanha-me nos cursos de formação, dentro e fora da Universidade. Acompanha-me nas minhas andanças pelo mundo afora.

É nela que guardo panos de várias cores, com diferentes texturas, retalhos, fios, botões e agulhas. A minha história.

Foi nesse movimento de abrir a mala, de olhar para as coisas, que achei o fio que tanto procurava para o meu trabalho para a exposição.

Com isso, revi também um material que usei num projeto junto com as crianças da Escola Balão Vermelho', em 2005. Denominei esse projeto "Segredos do Coração". Neste, inspirei-me na lenda indígena Kuarup, dos índios Kaiamurá, na qual celebram o ciclo da vida e da morte. A partir dessa lenda, propunha que as crianças costurassem pequenas almofadas (patuás), recheadas com escritos, como: segredos, tristezas, alegrias, dores e sofrimento. E inspirados nessa lenda, na experiência deste costurar, os patuás eram colocados no tronco de uma árvore, símbolo da vida, acolhedor da dor.

1 Escola de Educação Infantil e Ensino Fundamental, da rede particular de ensino, de Belo Horizonte MG.

Revista Digital do LAV - Santa Maria - vol. 11, n. 2, p. 230 - 244 - mai./ago. 2018 ISSN 1983 - 7348 http://dx.doi.org/10.5902/1983734832833905 


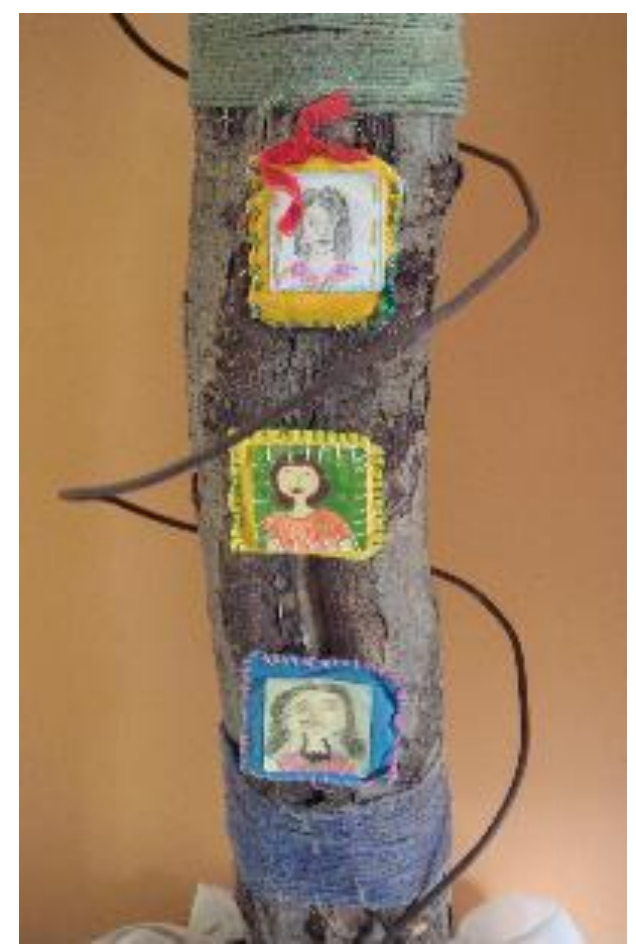

Figura 04. Segredos do Coração

\section{A mesa posta}

Naquela manhã, início de semestre, eu cheguei mais cedo à Universidade, inclusive antes do ônibus. A Universidade é distante e os alunos vêm de longe. Eu já os conhecia, porque alguns foram meus alunos no primeiro período. Não éramos muitos. Iniciei a aula. Pedi para que cada aluno trouxesse, por escrito, as suas primeiras experiências estéticas. Num outro dia, acompanhando a leitura das primeiras experiências estéticas, Viviane, uma aluna, propôs mudar a disposição das cadeiras e mesas da sala de aula: "Vamos ficar mais perto!", disse ela. Juntamos as pranchetas de desenho, que estavam na sala, formando uma grande mesa. Para compor o cenário, Luíza, outra aluna, trouxe um bolo, e Fátima, professora da disciplina Metodologia de Pesquisa, trouxe o café e o chá. Tudo estava pronto. A aula poderia começar. Por alguns instantes, perdi-me naquela imagem da mesa e na atmosfera que aquela aluna intuitivamente criou.

Lembro-me como se fosse hoje. O olhar para o aconchego da mesa, o bolo, o chá, os alunos sentados ao redor, um olhando para o outro, esperando o começo da aula. Todos presentes, menos eu, mentalmente é claro. Meus pensamentos voavam da sala de aula para a casa da minha infância e de lá para a sala de aula.... Estavam ali na minha frente: a mesa posta, o bolo, o chá e o café da casa aberta. Uma imagem que fazia parte da minha história, da minha vida de pequena. O movimento dessa aluna levava-me à minha 
casa antiga, aos meus guardados, fotos, livros, móveis antigos, aos meus bordados, à minha história. Um lugar acolhedor, onde existia sempre uma casa aberta e uma mesa posta.

\section{Alguém viu a instalação na Praça Milton Campos?²}

Alguém viu a instalação na Praça Milton Campos? Essa foi a minha pergunta para uma turma de alunos do segundo período de Licenciatura de Educação Artística, depois do feriado de Finados de 2009. Vinte alunos olharam-me: "Como assim?", "Aonde?", "Instalação?", "Na Afonso Pena? Não vi." "Eu também não... e hoje já passei duas vezes por lá".

Apenas uma aluna disse: "Sim, eu vi uma senhora com duas crianças pequenas montando o trabalho... eu acho que ela fez alguma homenagem... para alguém da sua família que morreu... inclusive ali tinha uma igreja antigamente..."

Depois da observação da aluna, alguns alunos ficaram curiosos e sentiram-se incomodados com o não visto naquela manhã, pós-Finados.

Ao sair da aula, passei perto do lugar da instalação, parei o carro e fui olhar de perto o que aquela senhora tinha feito; pois, até então, só tinha visto de longe. E qual não foi a minha surpresa?

A aluna tinha razão: era uma homenagem. Um altar montado com uma cruz toda envolta em um pano branco, com flores de pano, alguns santos, uma boneca de pano e fotos antigas de lugares da cidade de Belo Horizonte, que já não existem. Fazia parte da instalação um pequeno texto onde estava escrito que no dia 02 de novembro de 2009 o Instituto Moreira Sales fechara definitivamente a sua sede em Belo Horizonte. Era uma homenagem/denúncia. Senti como se aquela fosse uma homenagem para todos nós, vivos e mortos. Para mim.

Outro dia, a caminho da aula, passei novamente por lá. Contemplei de longe a instalação, com uma vontade de querer guardar para sempre...

$\mathrm{Na}$ volta passei novamente e vi um pequeno fogo, havia fumaça... O trabalho já não existia. Apenas um pano branco com uma cruz de cinzas no chão. Fui embora com uma vontade de chorar.

2 Instalação. Artista: Juliana Gouthier, 2009.

Revista Digital do LAV - Santa Maria - vol. 11, n. 2, p. 230 - 244 - mai./ago. 2018 ISSN 1983 - 7348 http://dx.doi.org/10.5902/1983734832833905 

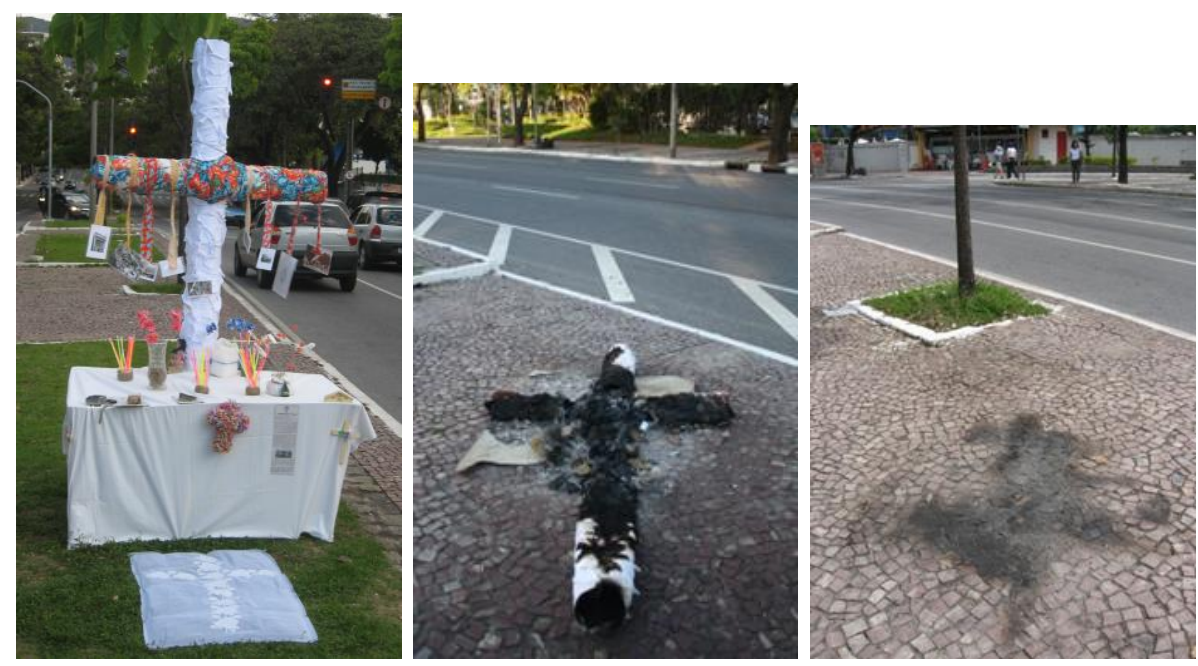

Figuras 05, 06 e 07. Instalação-denúncia. Artista: Juliana Gouthier, 2009.

\section{Para lecionar arte, compro uma revista na banca?}

Um dia uma ex-aluna, já formada, telefonou-me em busca de sugestões para dar aula.

- Desculpa, professora, por ligar no sábado para sua casa..., mas eu passei no concurso da prefeitura e segunda-feira começo a dar aulas....

- Na segunda? Mas você já sabe a turma que vai pegar?

- Não. Mas no meu desespero comprei uma revista na banca... quem sabe... acho algo lá...

- Mas... revista na banca?... e aí, achou algo interessante?

- Não, nada muito bom. Mas achei um roteiro de viagem para as férias... praias no Espírito Santo que eu gostei muito.

\section{- Espírito Santo? Praias?}

Nesse momento, caiu a ligação, e nunca mais ela me ligou.

Desliguei o telefone e pensei: Que aluna é esta que estou formando na Universidade e que, depois de vários períodos de prática de ensino, precisa correr para uma banca de revista para alimentar a sua prática de dar aula?

Depois desse telefonema, fiquei na dúvida se ela, na segunda-feira, foi assumir as aulas ou se foi embora para a praia.

Revista Digital do LAV - Santa Maria - vol. 11, n. 2, p. 230 - 244 - mai./ago. 2018 ISSN 1983 - 7348 http://dx.doi.org/10.5902/1983734832833905 


\section{Feijão Andu ${ }^{3}$ e Dona Emília}

Observo a artista no seu processo de criação, sentada no chão, com os pés descalços, despejando feijão à sua frente, iniciando um movimento com os pés e com as mãos, espalhando, ajuntando, organizando, recolhendo, colocando, retirando e pegando os grãos.

Assisto a sua performance e deixo envolver-me pelo clima de absoluto silêncio, de pausa. O gesto repetitivo cativa-me. É no movimento de catar, limpar, tirar, escolher e juntar novamente as impurezas catadas; enfim, na ação dos gestos que se repetem, que ela conduz o meu olhar. Aos poucos, o círculo ao seu redor cria forma e acolhe a artista.

Ao observar a performance desenvolvida a partir da sua memória de infância, lembreime novamente da cidade de São Leopoldo/RS, do Morro do Espelho e do Colégio Sinodal, escola de influência alemã e luterana na qual morei e estudei. Durante anos, essa escola tinha alunos internos. Lembro-me dos grandes dormitórios, de uma cozinha e um refeitório enorme e dos muitos funcionários.

A performance transportou-me para esse lugar, ao encontro de Dona Emília, que trabalhava na cozinha catando feijão. Não me lembro, nos anos em que morei lá, de tê-la visto fazer outra coisa a não ser catar feijão para alimentar os 500 alunos internos. Por meio de minha mãe, soube que ela e outras senhoras, que trabalhavam na cozinha da escola, chegaram lá ainda meninas, querendo trocar a vida sofrida do campo pela da cidade. Lembro-me de Dona Emília, uma senhora magra, de cabelos grisalhos, de óculos, de pouca conversa, calada.

\section{A professora que sou}

Ao escolher as histórias aqui narradas, tive a intenção de trazer alguns fragmentos que fizeram parte da minha prática docente e artística. São "flashes fotográficos, não estáticos, mas sim em movimento. Não são monumentos da história - cenas congeladas de acontecimentos -, são ação, constante produção" PETRUCCI ROSA, 2007, p. 27). Escolhi a narrativa como método, privilegiando ouvir as histórias daqueles que vivem a prática e o cotidiano da escola.

Para Petrucci-Rosa (2017, p. 560) "A narrativa encontra-se intimamente relacionada ao ato de rememorar, a possibilidade de ressignificação da própria experiência através das memórias cheias de significados, sentimentos e sonhos."

Nesse sentido, ao narrar as histórias da forma como fiz, ao contar o que aconteceu e se passou na sala de aula, reafirmo a minha opção pela abordagem teórica e metodológica

3 Performance da artista Amanda Lopes, 2008.

Revista Digital do LAV - Santa Maria - vol. 11, n. 2, p. 230 - 244 - mai./ago. 2018 ISSN 1983 - 7348 http://dx.doi.org/10.5902/1983734832833905 
da pesquisa autobiográfica. É a partir dessa abordagem que construo uma escuta atenta, cuidadosa com a história, a memória e o afeto de cada um.

Recentemente, ao observar os alunos narrando e desenhando as suas memórias durante as aulas de prática de ensino, percebi indícios potencializadores e autoformadores na construção dos seus caminhos como professores. Isso reforça a minha proposta de trabalho com a narrativa autobiográfica "como método de investigação, como processo de autoconhecimento e de intervenção na construção identitária de professores" (ABRAHÃO, 2008, p. 83). Uma construção identitária, onde tenho a impressão de sempre olhar e querer ver o avesso da minha tarefa de ser professora. Com isso, muitas vezes, conduzo o meu olhar e o dos alunos para o avesso das coisas. É como se a costura de dentro interessasse-me. É como se o meu olhar me levasse para lugares e pessoas que vivem nas fronteiras, nos entrelugares.

Constantemente, dirijo o meu olhar para os artistas que produzem a sua obra na margem dessa costura, na margem da caracterização como produção artística ou arte. Katia Canton (2009) ajuda-me a pensar sobre isso, quando aponta a serventia da arte:

E para que serve a arte? Para começar, podemos dizer que ela provoca, instiga e estimula nossos sentidos, descondicionando-os, isto é, retirando-os de uma ordem preestabelecida e sugerindo ampliadas possibilidades de viver e de se organizar no mundo (CANTON, 2009, p. 12).

Sinto-me reforçada no meu caminho como professora-pesquisadora-artista quando penso nessa ampliação e possibilidades que a arte pode provocar no ser humano.

Faz parte da minha prática docente levar, para a sala de aula, obras de artistas que nem sempre estão nas listas dos artistas mais renomados, ou mais indicados pela academia no campo da arte. Esse tem sido um caminho bastante frequente e prazeroso na minha prática docente e artística. Penso que esse foi o movimento que fiz, a partir do exercício memorialístico realizado com a escrita deste texto, quando olhei para a cesta de costura, para os patuás que acolhem a dor, para a Dona Emília catando feijão, para a mesa de costura, para a instalação da praça Milton Campos, para a casa aberta e a mesa posta.

Ao reler as histórias aqui narradas e vividas por mim, percebo que elas, mesmo que tenham acontecido em tempos e épocas diferentes e que, aparentemente, não tenham uma inter-relação, apresentam um elo de ligação entre si e não deixam de trazer indícios da minha prática artística e docente: da professora que sou.

Revista Digital do LAV - Santa Maria - vol. 11, n. 2, p. 230 - 244 - mai./ago. 2018 ISSN 1983 - 7348 http://dx.doi.org/10.5902/1983734832833905 
Penso que participar de uma exposição de arte na Croácia, com outras mulheres-artistaspesquisadoras-professoras, fez parte de um indício da minha prática artística, que foi motivada e alimentada por um trabalho de costura vivido junto com as crianças pequenas, em 2005. Inspirada no trabalho que desenvolvi com os alunos naquele momento, permiti-me um novo caminho, um processo de criação.

Dessa forma, a imagem da casa aberta e da mesa posta, lembrada por uma pessoa no dia do enterro do meu pai, possibilitou-me voltar ao meu passado, à casa da minha infância, estabelecendo um elo de ligação com a minha prática docente no curso de Licenciatura e nas aulas de prática de ensino. Assim, em 2009, a mesa posta, "casa aberta", foi incorporada ao espaço da sala de aula. Toda quinta-feira de manhã, reuníamos ao redor da mesa com bolo, chá e café. Líamos em voz alta as nossas reflexões e observações sobre o estágio supervisionado e os temas escolhidos para o Trabalho de Conclusão de Curso. Durante um ano, os alunos e eu tornamo-nos cúmplices da mesma mesa, da mesma casa, da nossa história.

Inspirada nas ideias de Bachelard (2005), ou seja, a casa sendo um espaço da acolhida, resolvi criar, a partir da experiência docente, um grupo de formação com professoresartistas-pesquisadores. Este grupo reúne-se uma vez por mês para desenvolver o projeto "Casa aberta, mesa posta". O objetivo é criar um espaço de conversa sobre as nossas experiências no campo da arte e da educação.

Alguns dias atrás, li um texto da pesquisadora canadense Rita Irwin que gostei muito. Ela destaca que: "Talvez todos os educadores desejem se tornar artistas-pesquisadoresprofessores quando começam a se questionar sobre como têm ensinado e como os métodos tradicionais precisam da vida e de viver" (IRWIN, 2008, p. 91). Talvez sejam estas as minhas intenções como professora e formadora: criar um lugar da acolhida, da escuta silenciosa de cada um, onde aprendamos a dividir e compartilhar as nossas histórias, ler os nossos textos, desenhos, costuras, ler a nossa vida; criar um movimento intenso, onde o desejo de tornar-se professor-artista-pesquisador possa ser construído por todos nós. 


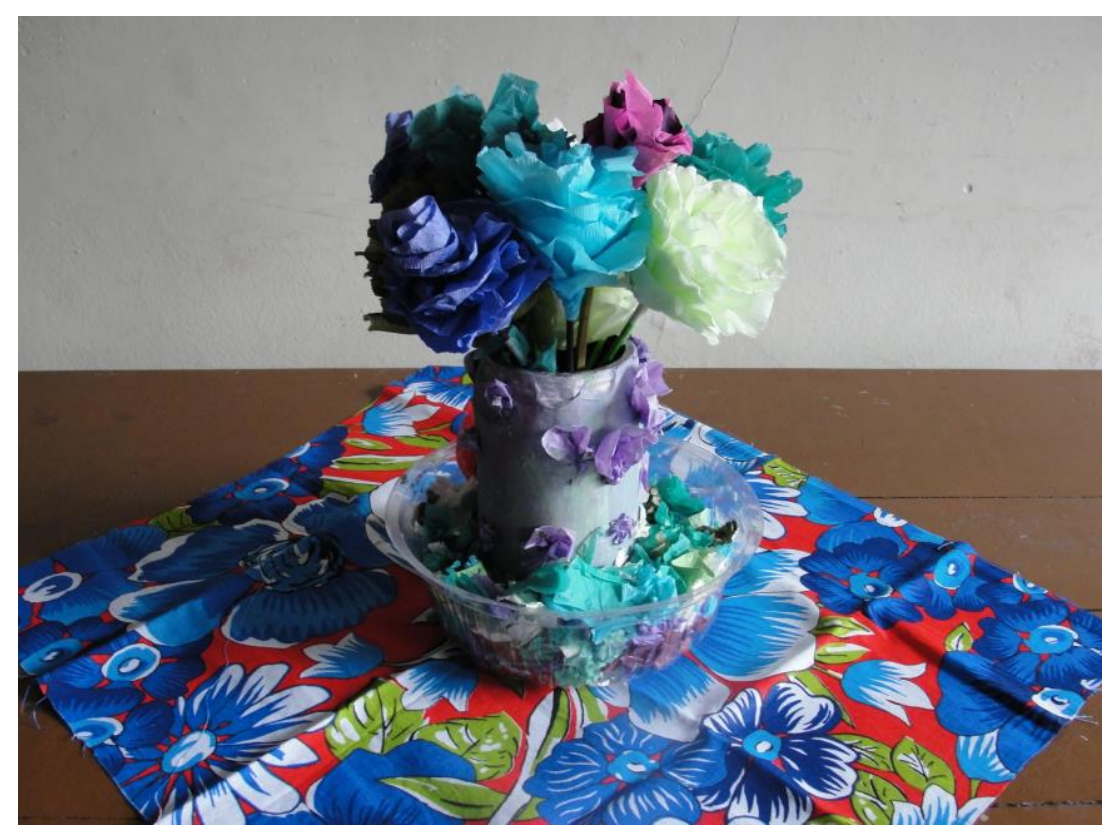

Figura 08. Flores de papel

Agradecimento

À Fundação de Amparo à Pesquisa do Estado de Minas Gerais FAPEMIG, pelo apoio recebido, em forma de bolsa, para a realização da minha pesquisa de doutorado em que abordo temas tratados neste texto.

\section{Referências}

ABRAHÃO, M. H. M. B. (Org.) Pesquisa (auto)biográfica e práticas de formação. Natal, RN: EDUFRN; São Paulo: Paulus, 2008.

BACHELARD, G. A poética do espaço. São Paulo: Martins Fontes, 2005.

BAUDRILLARD, J. O sistema dos objetos. São Paulo: Perspectiva, 2002,

BENJAMIN, W. Rua de mão única. 2. ed. São Paulo: Brasiliense. 1987. (Obras escolhidas v. 2).

Rua de mão única. 2. ed. São Paulo: Brasiliense. 1987. (Obras escolhidas v. 1). 
GALZERANI, M. C. B. Imagens entrecruzadas de infância e de produção de conhecimento histórico em Walter Benjamin. In: FARIA, A. L. G.; DESMARTINI, Z. B. F.; PRADO, P. D. (Orgs.) Por que uma cultura da infância: metodologias de pesquisa com crianças. 2. ed. Campinas: Autores Associados, 2005. p. 62

CATON, K. Narrativas enviesadas. São Paulo: Martins Fontes, 2009.

DELORY-MOMBERGER, C. Biografia e Educação: Figuras do indivíduo-projeto. Natal, RN: EDUFRN; São Paulo: Paulus. 2008.

FREIRE, P. Pedagogia da autonomia. Saberes necessários à prática educativa. 30. ed. São Paulo: Paz e Terra, 2004.

IRWIN, R. A/r/tografia: uma mestiçagem metonímica. In: BARBOSA, A. M; AMARAL, L. (Org.). Interterritorialidade mídias, contextos e educação. São Paulo: Editora Senac, 2008. p. 87-104.

PRADO, G. V. T.; et al. GEPEC: da educação continuada ao desenvolvimento pessoal e profissional em uma perspectiva narrativa. In: SOUZA, E. C.; PASSEGGI, M. C.; ABRAHÃO, M. H. M. B. (Org.). Pesquisa (auto)biográfica e práticas de formação. Natal, RN: EDUFRN; São Paulo: Paulus, 2008. p. 59-74.

PETRUCCI-ROSA, M. Práticas Curriculares na formação profissional: uma compreensão singular para as narrativas como forma de transgressão, Linhas Críticas, v.23, n.52, p. 560-577 (2017).

PETRUCCI-ROSA, M. I.; BONAMIGO, C.C. ; CORRADI, D. P. ; PARMA, M. ; PAVAN, A. C. ; RAMOS, T. A. ; VARSONE, A. . Narrar currículos: inventando tessituras metodológicas. In: Antonio Carlos Amorim. (Org.). Passagens entre o moderno e o pós-moderno: ênfases e aspectos metodológicos das pesquisas sobre currículos. Campinas: FE/UNICAMP, 2007, v. único, p. 29-35.

i Professora da Escola de Belas Artes da Universidade Federal de Minas Gerais. Doutora em Educação pela Universidade Estadual de Campinas (UNICAMP - 2011). Licenciada em Desenho e Plástica pelo Centro Universitário Feevale (1979), Especialização em Arte-Educação pela USP (1987). Obteve o título de Mestre em Educação pela Pontifícia Universidade Católica de São Paulo (1991). Lecionou Arte no Ensino Fundamental de 1978 a 2013. Foi professora do curso de Estilismo e Moda da Universidade Federal de Minas Gerais (UFMG) de 1993 a 2005. Lecionou no ensino superior privado em diversas instituições. Entre 2006 e 2016 foi professora do Ensino Superior da Universidade do Estado de Minas Gerais (UEMG) Escola Guignard, onde lecionou para cursos de graduação e pós-graduação. É assessora das proposições 
curriculares da educação infantil da Prefeitura de Belo Horizonte. Tem experiência na área de ensino de Arte e Educação, atuando principalmente nos seguintes temas: formação de professores, educação infantil e fundamental, educação estética, narrativas de formação, abordagem autobiográfica, história de vida.

Como citar esse artigo:

BERNARDES, Rosvita Kolb. De uma história a outra, a professora que sou. Revista Digital do LAV, Santa Maria: UFSM, v. 11, n. 2, p. 230-244, mai./ago. 2018. 